\title{
Harvard University's Widener Library Shelflist Conversion and Publication
}

\section{Program}

\begin{abstract}
This paper briefly reviews the essential background and reports on the progress, evolution and future outlook of this unique program. It then describes in some detail the present and potential uses that can be made of the shelflist of a major research library after it has been converted to machine readable form and can be manipulated by computer. The uses fall into two broad categories: publications and reader services, and library management and statistical uses. It is a nontechnical article for librarians and library users.
\end{abstract}

\section{INTRODUCTION}

$I$ N 1964 WIDENER LibRARY, the central research collection of Harvard University, developed a system for converting its manuscript sheaf shelflists to machine readable form and embarked on a project to computerize the 1.6 million entries in the list. To date, more than 600,000 records from some of the most active classes in the library have been converted and used in various ways, and the project continues as an accepted and important part of the library's automation operations. The project has now come of age; its feasibility and usefulness are firmly established and it seems appropriate at this time to review briefly the essential background of the program and to report on its progress, evolution, and future outlook.

The previous papers on the Widener

At the time this paper was written, Dr. De Gennaro was Senior Associate University Librarian, Harvard University. He is now Director of Libraries, University of Pennsylvania. shelflist project were largely concerned with the strategy and the techniques of converting this large and unique file into machine readable form. This paper will stress the present and potential uses that can be made of the shelflist of a major research library after that conversion (or a large part of it) has been completed. Two main categories of uses will be discussed: (1) the production of publications of various kinds and the provision of other reader services; and (2) library management uses including the generation of statistical and other data for further automation, for managerial purposes, and for general research.

\section{Review of the Project}

The justification for embarking on the ambitious project to convert the estimated 1.6 million handwritten entries in the old loose-leaf sheaf shelflists in Widener Library can be found in an article entitled "A Computer Produced Shelflist" which appeared in CRL in 1965..$^{1}$ The project was placed in the larger context of the Harvard Library's overall automation program in another article, "Auto- 
mation in the Harvard College Library" which was published in $1968 .^{2}$ A technical description of the operation in its early stages was written by Foster M. Palmer in $1966 .{ }^{3}$ No detailed technical descriptions of the computer systems have been published since that time, although specific information can be obtained from internal working documents. The preparation for publication of technical descriptions of a rapidly evolving system of a local nature is time-consuming and difficult to justify. This article will merely sketch in enough of the project's background to make it comprehensible without reference to the earlier papers. No technical material will be included.

A library shelflist is a record of the books arranged in the order in which they appear on the shelves. It is maintained primarily as a tool for assigning new and unique numbers to books that are added to the collection and as an inventory record of the books in a library. Since the book collections in most American libraries are arranged in classified order, the shelflist is potentially useful to scholars, particularly if it can be made available in convenient form and if classification schedules and author and title indexes are provided. For most libraries the maintenance of a shelflist is a routine process and involves merely filing a copy of each main-entry card into the card shelflist in call-number order. However, the Widener shelflist, for historical reasons, is largely handwritten in loose-leaf volumes, rather than on cards, and is therefore difficult to use and maintain. In 1964 it became evident that, through the use of computer technology, the library could modernize the shelflist maintenance procedure and at the same time make an expanded version of the shelflist available as an additional approach to the library's holdings. Accordingly, an experimental system was designed to convert the shelflist to machine readable form and, after a successful pilot project, a full-scale conversion and publication program was begun in 1965 .

The initial system was somewhat primitive, with input and output limited to the standard uppercase character set that was then commonly available on computer print chains. In June 1966 the system was improved so that the input could be coded with an expanded character set to produce output with both upper- and lowercase letters and the required diacritical marks. The output for the published volumes continued to be produced by photo offset from a computer printout until further improvements in the system made it possible, late in 1969, to produce graphic arts quality printer's copy in double columns by computerized photocomposition techniques. The evolution of the output format is virtually complete; all further improvements will be in the input, processing systems, and development of new products.

To date, more than 600,000 entries of the total 1.6 million in the shelflist have been converted. Twenty-two volumes have been published in the Widener Library Shelflist series and a dozen more are scheduled for publication in 1970 . An estimated twenty-five to thirty additional volumes will be required to complete the series. Several of the classes that were initially keypunched in the limited uppercase format have been converted by a combination of computer program and manual editing to the new standard expanded character set and format, while the rest will be completed by the end of the year. Thus, all the records in the system will soon be in a single uniform and compatible machine format. The master files are arranged in classified or shelflist sequence on magnetic tape. Widener call numbers are machine processable and, since the numbers are unique, they also serve as identification numbers for the machine records.

The entries in the old manuscript 
shelflists are not bibliographically complete. They were limited to call number, volume count, author, title, place, and date of publication. Frequently the author's forenames were not spelled out and the titles were shortened. Notes, added entries, and subject headings were not included. The strategy of the conversion project is to accept the entry essentially as it is with some few exceptions; obvious errors are corrected, authors' full names are added when easily obtainable, abbreviations in titles are spelled out, and a language code and a code distinguishing serials from monographs are added. All elements present are tagged so as to permit machine manipulation. The average number of characters per record is 100 , while full LC records are estimated at $350-450$ characters. This enforced limitation on the quality and completeness of the records is unfortunate for many reasons, but it has made the conversion and publication projects economically and technically feasible. Had the shelflist contained complete bibliographical records, the project would not have been attempted, for various reasons.

Since clean and accurate copies of the Widener classification schedules are a necessary prerequisite for the preparation of the published shelflists, a major program was undertaken in 1966 to revise and edit the schedules. The schedules are being converted to machine readable form, and a computer program nsed to facilitate editing as well as to format them into the two distinct forms that are required for the published lists.

All shelflist conversion and editorial work is done in the library with regular library funds by a staff of eight nonprofessionals. It has become a routine activity of the Data Processing Division and funds for the completion of the project within the next several years seem assured.

The design and programming of the system has been accomplished entirely by librarians trained as systems analysts. The routine computer work has been done for the most part on an IBM 1401 which has 8,000 positions of core storage and four tape drives and is located in the library. In 1970 the 1401 will be phased out after the entire system has been redesigned and reprogrammed to run on an IBM 360-65 located in the University's Computing Center. The system conversion will be done by the library's data processing staff. The occasion will be seized to convert the local shelflist system into a more permanent and standardized system based on the MARC II format. When the present system was designed, the MARC II standard format for bibliographic entries in machine readable form did not exist. That format has now been completed and widely accepted internationally, and programs are being written at several centers to manipulate bibliographic data in that format in various ways and for various purposes.

Although Harvard shelflist entries are not as complete as full LC MARC II entries, the elements that are present can be tagged and put into the format, and those that are not can be left blank. When the library develops a system to input its current cataloging in the MARC II format, those entries can be integrated into the new shelflist system, since the machine format of the two kinds of entries will be compatible even though they differ in the amount of data included.

In the more distant future it is expected that the present brief shelflist entries will be superseded by standard bibliographical records in MARC II format. Given the growing interest in retrospective conversion at the national level, it is reasonable to foresee that a central bibliographical agency will convert and distribute these entries and that Harvard may be able to substitute them for its own incomplete entries. ${ }^{4}$ But this is a distant and as yet uncertain possibility. 
Meanwhile, Harvard will have realized a satisfactory return on its investment in converting its abbreviated shelflist entries. The nature and extent of that return is the subject of the remainder of this paper.

\section{Uses of the Machine Readable DATA BASE}

The present and potential uses of the Widener shelflist data base fall into two broad categories. The one involves creating and publishing new or special listings of the holdings of the library for the use of scholars, bibliographers, and librarians at Harvard and elsewhere. The prototype is the published shelflist series; this series and its possible future variations will be discussed first. The other involves using the machine readable data base to improve or facilitate certain library operations such as shelflist maintenance, circulation control, collection building, and the generation of statistical and other information for management and analysis purposes.

\section{Publications and Reader Services}

The publication of the Library's shelflist was one of the principal justifications for converting the shelflist to machinereadable form. The rationale is stated succinctly in the preface to the published volumes:

In the absence of a classified catalog, the shelflist has long been used by librarians and experienced library users as a means of systematically surveying the library's holdings in a particular subject. When perusing the shelflist one sees all the titles that have been classified in a given area, and not merely those which happen to be on the shelves and whose spine lettering is legible. In addition, one can take in at a glance the essential bibliographical description of a book-author, title, place and date of publication. However, the potential usefulness to readers of the Widener sheaf shelflist in manuscript form has never been realized because it existed in only one copy. Moreover, it was kept in a relatively inac- cessible area, was awkward to read and frequently difficult to interpret. Computer technology has made it possible to enlarge the concept and to expand the uses of the shelflist while improving the techniques of maintaining it and making it available to readers. . . . The development and publication of the shelflist in this form is an attempt to equip the serious reader with a copy of the classification scheme that has been used to organize the collection, together with lists in classified, alphabetical, and chronological order of the books and journals in each class.

After each class and its corresponding classification schedule have been converted to machine readable form, a three-part catalog of the holdings in the class is published in the Widener $\mathrm{Li}$ brary Shelflist series. The first part contains the classification schedule and a list of the entries in the class in call number (i.e., classification) sequence with subclass headings (derived by program from the machine readable classification schedule) interspersed throughout the list. The second part is an alphabetical listing by author and by title and is obtained by a programmed computer sort of the original entries, and the third part lists each entry again chronologically by date of publication. Thus, each entry is listed four times.

The first twenty volumes in the series were produced by photo-offset from photographically reduced computer printouts and averaged about seventy entries per single-column page. Beginning with volume 21 , all page copy has been set in 6-point Times Roman type in double columns by a computerized photocomposition technique, with approximately 140 entries per page. Volumes are $8 \gamma_{2}^{\prime \prime} \times 11^{\prime \prime}$, printed on durable paper, and cloth bound. The library is the publisher.

The published volumes are extensively used in the Harvard libraries in a variety of ways by both readers and staff. Sets of the entire series are located in reading rooms for reference and in the stacks for circulation to readers. Copies 
of the volumes covering particular classes are located in special boxes attached to the end panels of the stacks in which the class is located and are used by readers as browsing guides and as convenient finding lists. The availability of the series also tends to reduce somewhat the objections to shelving infrequently used books by size in storage areas outside the library, because these titles are retained in the shelflist with a symbol showing the actual location of the book in storage. The volumes are also used by book selectors in building collections as well as by inter-library loan staff, both at Harvard and in other libraries. Since the shelflist volumes form subject catalogs of specific portions of the collection, and since, unlike book catalogs of entire libraries, they can be purchased separately, many individual scholars acquire personal copies of the volumes covering their field.

All costs of the shelflist conversion project, including systems development, conversion, editing and machine costs, have been borne entirely by the library from regularly budgeted funds. All costs incurred in the actual publication of the series, including final computer sorts, photocomposition, printing, binding and distribution, are met from sales receipts. Within this framework the published series has been self-supporting from its inception. The rationalization for this large expenditure of library funds is that conversion of the old manuscript shelflist is a necessary improvement of the library's record-keeping operations and that the investment in conversion (an estimated thirty cents per entry) will be amply justified by long-term savings in shelflist maintenance and other library management gains. Other savings-impossible to measure-are in the time and effort of readers and staff who use the printed shelflist catalogs in lieu of going to the card catalogs. James L. Dolby makes this point nicely in his recent book on computerized book catalogs:
In particular, we claim that no careful study is necessary to show that a printed catalog on the desk of the user, or at least in the immediate vicinity of his office, is a sufficient advance over the present card catalog to provide a substantial time advantage in his use of the catalog. At the very least, the user is saved a trip to the library for all those searches that prove to be fruitless. Further, in an automated catalog it is feasible to produce many more different orderings of the catalog (and subsets thereof) than is feasible in a card system. This in turn increases the number of access points to the library collection and the over-all utility of the catalog to the user. It may be difficult to put a precise dollar figure on the value of added access, but at the first level it is certainly sufficient to offset minor cost increments in the cataloging operation. ${ }^{5}$

The selling price of the individual volumes ranges from $\$ 10$ to $\$ 45$ and is based on the number of pages, the estimated sales potential of the particular volume, the manufacturing cost, and in special cases, such as the Slavic class, the amount and cost of extra editorial work.

Since the shelflist in this form was a new and unfamiliar kind of bibliographical tool, and since the promotion efforts were deliberately limited, sales were initially slow and tended to be limited to the larger American research libraries, many of which placed standing orders for the series. Sales have increased as the series has become larger and better known and as the format has been improved. The market for volumes has ranged from four to eight hundred copies, depending on the subject covered; while further improvement is possible, it is unlikely that the sales of any volume will exceed a thousand copies. There has been a market for these volumes because they list the holdings of one of the world's great research libraries and as a result are valuable tools for librarians and scholars. To date the following volumes have been published or are in preparation: 
Volumes Published:

1. Crusades. 1965.82 pp., 1,202 titles. \$3. Out of Print.

2. Africa. 1965. 790 pp., 13,335 titles. \$25. Out of Print.

3. Twentieth-Century Russian Literature. 1965. 428 pp., 9,430 titles. \$20. Out of Print.

4. Russian History Since 1917. 1966. 698 pp., 13,722 titles. $\$ 30$. Out of Print.

5-6. Latin America. 1966. 1,492 pp., 27,292 titles. 2 vols., $\$ 65$.

7. Bibliography. 1966. 1,066 pp., 19,643 titles. $\$ 40$.

8. Reference Collections. 1966. 187 pp., 4,300 titles. $\$ 10$. Out of Print.

9-13. American History. 1967. 4,087 pp., 83,867 titles. 5 vols., $\$ 175$.

14. China, Japan and Korea. 1968. 494 pp., 11,388 titles. $\$ 25$.

15. Periodical Classes. 1968. 758 pp., 25,685 titles. $\$ 25$.

16-17. Education. 1968. 1,610 pp., 32,722 titles. 2 vols., $\$ 60$.

18. Literature: General and Comparative. 1968. 189 pp., 5,065 titles. $\$ 10$.

19. Southern Asia: Afghanistan, Bhutan, Burma, Cambodia, Ceylon, India, Laos, Malaya, Nepal, Pakistan, Sikkim, Singapore, Thailand, and Vietnam. 1968. 543 pp., 10,292 titles. $\$ 20$.

20. Canadian History and Literature. 1968. 411 pp., 10,212 titles. $\$ 17.50$.

21. Latin American Literature. 1969. 498 pp., 16,900 titles. $\$ 40$.

22. Government. 1969. 263 pp., 7,190 titles. $\$ 20$.

Volumes in Preparation:

23-24. Economics. 1970. 1,800 pp., 65,000 titles. 2 vols., $\$ 95$.

25. Celtic Literature. 1970. 192 pp., 7,500 titles. $\$ 25$.

26-27. American Literature. 1970.
1,600 pp., 50,000 titles. 2 vols., $\$ 95$.

28-31. Slavic History and Literatures. 1970. 2,700 pp., 93,000 titles. 4 vols., $\$ 190$.

32. General European and World History. 1970. 35,000 titles. $\$ 50$.

33. Reference Collections. 1970. 160 pp., 5,000 titles. $\$ 10$.

34. African History and Literatures. 1970.500 pp., 16,000 titles. $\$ 35$.

English Literature. 1971. 108,000 titles.

Finnish and Baltic History and Literatures. 1971.

Spanish History and Literature. 1971.

Note: Another 25 to 30 volumes will be required for the remaining significant classes which are scheduled for publication. Many minor and lesser-used classes will not be published in the series.

In 1968, after a thorough analysis of the cost and other factors, a decision was made to change the output system to produce printer's copy by a computerized photocomposition process and to discontinue using line-printer output for publication. The logic behind the decision was that the increased page density of photocomposed text would reduce the number of pages in a volume by approximately one-third thus reducing printing costs by a similar amount, while increasing the quality and legibility of the book. Although the cost of creating a photocomposed page is several times the cost of a line-printer page, the increase would be more than offset by the reduction in printing costs. Experience proved that this was the case but the savings were not as great as anticipated because the cost of the additional computer time required to prepare the tapes for input into the photocomposition machine were underestimated. It costs slightly more to produce the photocom- 
posed volume, but this added cost is justified because it improves the quality of the finished book immeasurably. The slight increase in cost for producing printer's copy in this manner is a temporary penalty only; a significant drop in photocomposition costs can be expected in the next few years as the equipment improves, as the volume of business increases, and as the industry becomes more competitive. Even at current prices, photocomposition is a minor cost breakthrough for the production of book catalogs, particularly in large editions where the savings in printing and paper costs are important.

The relatively new COM (computeroutput-microfilm) technology may well provide the solution to the problem of producing small editions of book catalogs at acceptable costs. This process produces output from a magnetic tape onto 16 or $35 \mathrm{~mm}$ microfilm at tape running speeds. ${ }^{6}$ The cost of producing the film is considerably less than line-printer output, and the quality of the print image is somewhat superior to that of the line printer. However, it does not compare with photocomposed copy, which is significantly better but several times more costly.

The COM output can either be used in microfilm or automatically enlarged to full-sized master copy for reproduction in small editions. Because of the poorer quality product and other uncertainties, the COM process is not being considered as a possible alternative to the present photocomposition process. However, it is being considered as a means of maintaining the official shelflist and more will be said about this later.

In the longer range, and particularly after the entire shelflist has been converted, COM will offer many interesting possibilities for exploiting the shelflist data base so that a whole variety of listings in different sequences and for different purposes can be published in small, inexpensive microform or even full-sized editions depending on the need and use to be made of them.

The problem of issuing supplements or revised editions of the volumes in the current Shelflist series is a difficult one. The publication and distribution of supplements to the individual volumes is questionable from the point of view of both costs and usability. It has been rejected in favor of issuing new and enlarged editions when the basic volume has become seriously outdated, generally after five or more years. Thus, the contents of the first volume, Crusades, will be included as part of the General European and World History volume; volume 2, Africa, which was published in 1965, will be revised, enlarged and reissued in 1970 in the new photocomposed format; other early volumes in the series will be treated in a similar manner. In the future, the problem of publishing subsequent editions may well be solved by advances in technology and improvements in the economics of publishing. COM and reductions in the cost of photocomposition and computing are reasonable expectations in the near future.

As has already been suggested, these developments may make possible the publication of special or even custom listings of great usefulness, but of relatively limited demand. For example, upon completion of conversion of the entire shelflist it might be desirable and feasible to produce, by COM at an acceptable cost, an up-to-date microform edition of the entire file in classified, author and title, and chronological sequence. Listings by language would also be possible as would a listing of all serials and journals in the collection arranged in a single alphabetical sequence. Current accessions lists would be another useful product.

The technique of merging several related classes into a single sequence has already been accomplished with excel- 
lent results and could be further exploited. An example of this would be to expand the Slavic History and Literature class into a comprehensive Slavic area studies catalog by adding the Slavic titles from other classes such as Education, Folklore, Philology, Sociology, Government, etc. The technique could be applied to other areas such as Africa and Latin America. New shelflist-type catalogs of Judaica and other subjects might be created by pulling together the bibliographic entries that are located in the various country and literature classes as well as in Sociology, Folklore, etc. Miscellaneous scattered titles might be located by searching the tapes for certain key words in titles. The results would have to be edited to eliminate false drops but the process might be useful as a first pass. Similar techniques could be used to search the data base and create special or custom listings for individual scholars or groups on request.

When it becomes economically feasible to store such a large data file in a direct access device and to search and manipulate it from a cathode ray tube console, the possibilities for making interesting and novel uses of the data will be expanded enormously. While mass storage and on-line direct access is an operational technology today, it will probably be several years before it will be economically feasible in the research library environment. ${ }^{7}$ It seems idle, therefore, to speculate about these interesting but relatively remote possibilities in an article set in the context of current economic realities in libraries. Recent experience indicates that improvements in computer and photographic technology are occurring at an ever-accelerating rate, and the possibility of dramatic advances and cost breakthroughs in the next few years should not be discounted.

A long range but still realistic idea is the possibility of turning the conventional library shelflist into a kind of clas- sified catalog once it has been converted and is maintained in machine readable form. The basic difference between a conventional shelflist and a classified catalog is that the shelflist treats a book as a single physical object and records it only once, no matter how many subjects it covers, while a classified catalog records the book in as many places as its subject requires. With a computerized shelflist, the reason for this limitation no longer exists; a book can be given one number to record its physical location, and several other class or base numbers to indicate facets of content. Thus, a single book could appear several times and in various classes. The two types of call numbers would be distinguished by a symbol or other means, and these added entries could be printed or suppressed depending on the use to be made of the list. The introduction of this innovation in shelflisting can only be done after conversion has been completed and it has, therefore, not yet been proposed for the Widener shelflist.

\section{Library Management Uses}

The present system for adding entries to the official copy of the computerproduced printout shelflists is identical with the system for adding to the old manuscript shelflists. The machine lists are printed with five blank lines between the entries in order to leave space for writing in new additions. Periodically, and as the pages become crowded, all new entries and changes in the list are keypunched and added to the master tape file and a new printout replaces the old one. The inefficiencies of this procedure are obvious, but they were tolerated in the early stages of the conversion project on the grounds that it was preferable to have a single shelflisting procedure for both manuscript and machine-produced shelflists until such time as the proportion of machine lists increased to a point where a second system would yield significant savings. 
Now that more than a third of the shelflist, including many of the most active classes, is in machine form, the conceptual design of a machine based system for maintaining official copy has been developed and is being considered. It can be briefly described as follows: all classes in machine format would be updated and produced in an efficient single-spaced format on microfilm or microfiche using a COM (computer-output-microfilm) technique. This film would serve as the official shelflist copy along with a temporary card supplement. Book numbers for new books would be assigned by consulting both the film and the card supplement. The number would be preempted by making a temporary slip for it in the supplement, and this slip would be replaced by a unit card after it had been produced. Periodically the contents of the card supplement would be converted to machine form, merged with the master tape, a new cumulated official film or fiche version would be produced by $\mathrm{COM}$, and a new card supplement would be started. This procedure could be further simplified after developing and implementing a system to input current cataloging into machine readable form, but even in the interim the savings would be substantial. Assuming a cost of five cents per frame of microfilm containing 80 entries, the entire shelflist of 1.6 million entries would require 20,000 frames and could be produced for about $\$ 1,000$ on approximately 12 reels of film. A microfiche version would require only $2504^{\prime \prime}$ × $6^{\prime \prime}$ fiche.

Computer printing and other costs would be substantially less than in the present system. Shelflisting now requires a staff of four persons and an area of 600 square feet. It could probably be reduced to a single work station located in the cataloging room where it logically belongs, while reference copies could be maintained in other locations.

The completed shelflist file can be made to serve many of the purposes of a central bibliographical record in machine form. By running call numbers against this file a variety of products could be produced such as machine readable book cards for an automated circulation system, lists of overdue books, missing books, and books to be replaced or purchased in duplicate. In short, any list of call numbers could be expanded into full shelflist type entries by simply key-punching them and matching them with the data file by the aid of a program.

The records of the one and one-quarter million circulation transactions made in Widener since 1965 , when the machine system was installed, have been preserved on five reels of magnetic tape and constitute an invaluable and unique data base from which statistical analyses of the use of the collection have been made. ${ }^{8}$ One of the chief limitations of this file comes from the fact that the bibliographic data in the charge records is limited to call numbers. This limitation can be overcome by using the call numbers to extract the complete entries from the shelflist file. Thus, for example, listings of the most frequently used titles could be obtained by sorting the charges in the order of frequency of use and using the resulting call numbers to obtain a listing of the bibliographical entries from the master shelflist file. Decisions about where to locate material in the library and which material to send to deposit collections can be made on the basis of these statistics. Such potentially useful management information has never before been available to library administrators.

Another area of statistical analysis that is opened by the existence of the master shelflist file is the analysis of the collections themselves, their make-up, their rate of growth over the years and in various subject areas. Detailed and accurate counts can be obtained of the individual classes and of the collection 
SAL 5611.14 .100

SAL. 5723.6 .100

SAL 7723.1.35

SAL 9125.19 .100

SAL 4870.18.120

SAL 5657.1.32

SAL 7113.35.120 SAL 9171.50 .120

SAL 9149.99 .4

SAL 9272.51 .140

SAL 321.1.15.15

SAL 1526.6 .110

SAL 922.55 .100

SAL 5679.86

SAL 7720.41 .200

SAL 1740.25 .5

SAL 7627.3.100

SAL 5513.12 .120

SAL 5206.65 .100

SAL 7189.14 .3

SAL 7780.3.41

SAL 9189.14 .220

SAL 9121.5 .120

SAL 8076.10.100 SAL 4327.66.1100

SAL 1731.33.100

SAL 296.41 .130

SAL 9226.41 .2800

SAL 9173.5 .110 SAL 9173.5 .100

SAL 4569.3 .100 SAL $4310.23,1$
Dialogos en "La reina del mar". (Garcia, J.J.) Bogotá, 1965.

Dialogos en otros mundos. (Restrepo, Felix.)

logos limpicos. v.I-2. (Reyles, C.) Buenos Aires.

Diálogos no espelho. (Bandeira, Antônio Rangel.) São
Paulo, 1968 .

Dialogos y "cuentos de mi paisaje". (Medinaceli, Carlos.) La Paz, 1963

Dialogos y juguetes escénicos. (Leon Gomez, Adolf.)

Diamantes y pedernales. (Arguedas, Jose M.) Lima, 1954.

Diamantina. (Delfino, Aldo.) Bello Horizonte, 1914

Madrid, 1964

Diário. Capa de Carlos Penafiel. (Cardoso, Lucio.) Rio de Janeiro, 1960?

Diário critico de Śŕrgio Milliet (1940-1943). (Milliet, S.)

São Paulo, 1944-45. 2v.
Diario de amor. (Gómez de Avellaneda, G.) Madrid, 1928? diario de Gabriel Quiroga. (Galvez, Manuel.) Buenos

El diario de Jose

Miguel.) México, 1964.

Diario de la montaña, 1957-1960. (Ramirez de Arellano de Nolla, Olga.) San Juan, 1967.

Diario de Lecumberri. (Mutis, Alvaro.) Xalapa, 1960.

Diario de naje a Paris. (Quiroga, H.) Montevideo, 1950.

Diario de nuestro viaje a los Estados Unidos. V. 2. (Sierra, Justo.) Mexico, 1938.

(Halegua, I.) Montevideo, 1960.

Diario de un peatón. (Arciniegas, German.) Bogotá, 1936. Buenos Aires, 1940 .
Burio de un solteron

Diario de una "patinadora". (Frontaura, Rafael.) Santiago de Chile, 1963?

Diario de viaje. (Escobar, Alberto.) Lima, 1958.

Diario de viaje. (Viana, Francisco Javier de.)

Montevideo, ls

De.) Rio de Ja

de.) Rio de Ja
Diario I- difícil é.

Janeiro, 1962.

Diario intimo. (M

Diario poético, ab

Aires, 1961.

Diario semanario

Xalapa, 1961.
Diarios de viajes.

Dias, Fernando Cerreía. José Alphonsus: tempo e modo. Belo

Horizonte, 1965

WIDENER LIBRARY SHELFLIST, 21

AUTHOR AND TITLE LISTING

Sas Paulo, 1960

Dias, Theophilo. O comedia dos deuses; poema. Săo

Paulo, 1887.

Los dias. (Uribe, B.) Buenos Aires, 1959.

Dias amargos; poesías. (Malde Vizoso, E.) Habana, 1915
SAL 5022.16

SAL 5137.1 .82

SAL 5218.19 .820

SAL 5020.17

SAL 5173.2 .21

SAL 5068.2

SAL 5022.15

SAL 1573.4 .100

SAL 5573.2 .3

SAL 1573.6.120

SAL 1573.6.100

SAL 1573.6.12

SAL 1573.6.110

SAL 6142.48 .800

SAL 9065.7

SAL 1573.7 .100
SAL 1573.7 .110
SAL 5173.5 .100
Diaz Arrieta, Hernán. Las cien mejores poesias chilenas. 3a ed. Santiago de Chile, 1957

Diaz Arrieta, Hernán. Los cien mejores poesías chilenas. 4 ed. Santiago de Chile, 1962

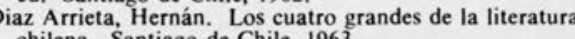

Diaz Arrieta, Hernán. Don Alberto Blest Gana. Santiago de Chile, 1940.

Diaz Arrieta, Hernán. Gabriela Mistral. Santiago de

Diaz Arrieta, Hernán. Historia personal de la literatura chilena. Santiago de

arrieta, Hernán. Leer y escribir. Santiago de

Caz Arrieta, Hernán. Memorialistas chilenos. Santiago de iaz Arrieta,

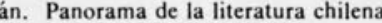
durante el siglo XX. Santiago de Chile, 193I. Diaz Bolio, J. El mayab resplandeciente. Mexico, 1934 Ciaz Casanueva, H. Réquiem. 3a ed. Santiago de Chile, 1958.

Castro, Eugenio, Manuela. Paris, 1889. $2 v$.

Diaz Castro, Eugenio. Una ronda de don Ventura Ahumada Diaz Covarrubias, Juan. Gil Gomez el insurgente; novela historica. Mexico, 1919.

Diaz Covarrubias, Juan. Impresiones y sentimientos. Mexico, 1857.

Diaz Covarrubias,

Diaz Covarrubias, Juan. Obras completas. la ed.
Mexico, 1954.

Mexico, 1859.

Cuenca, 1965.

nos Aires, 1946.

Diaz de Leon, Rafael. Por los pobres. Hermosillo, 1921.

íaz de Léon, Raf Mexico, 1923

Heroe de San Mateo. Pasto, 1914

Teatro: El pretor. Bogota, 1967. itmos de libertad; sonetos.

m. La voz del torrente, 2a ed. Santiago

Tipos de la Habana. Habana, 1895.

González, O. Collection of plays. 9 pam
io. Crónicas de Altocerro. Santo

SAL 3173.5 .700

SAL 3173.5.100

SAL 4705.89 .800

SAL 4773.23 .120
Diaz Lozano, Argentina, Enriqueta and I. N.Y. 1944 Diaz Lozano, Argentina. Peregrinaje. 2a ed.

emala, 1955

Diaz Lozano, Argentina. Peregrinaje. Santiago de

Diaz Machado, P. Nataniel Aguirre. Buenos Aires, 1945 Diaz Machicao, Porfirio. Cauce de palabras. La Paz, 1967. Pronica de cronicas. 
SAL 4231.5

SAL 4231.

SAL 4231.12

SAL 4231.12.12

SAL 4231.12 .15

SAL 4231.14

SAL 4231.15
Echaguë, Juan P. Teatro argentino. Madrid, 1917. Bianchi, A.A. Teatro nacional. Buenos Aires, Rodriguez Acasuso, L. Del teatro al libro. Buenos

Aires, 1920.
Echague, Juan P. Un teatro en formación. Buenos Aires, 1919

Echague, Juan P. Una época del teatro argentino 1904-18. 2 ed. Buenos Aires, 1926.

Oreve historia del teatin. Paris, 1927.

Aires, 1962-63. 8v.

Bastardi, Francisco. Yo también con mis memorias. Buenos Aires, 1963.

Blanco Amares de Pagella, Angela. Nuevos temas en el teatro argentino. Buenos Aires, 1965.

SAL 4232 Latin American literature in Spanish - Argentina - Histor

of special forms - Drama - Local

SAL 4232.1 Bosch, M.G. Teatro antiguo de Buenos Aires. Buenos

SAL 4232.1 .3

Bosch, M.G. Historia del teatro en Buenos Aires. Bueno

Aires, 1910.
Castillo, C. Historia de los origenes del teatro nacional

SAL 4232.1 .10

SAL 4232.2

SAL 4232.2 .3

SAL 4232.3

SAL 4232.5

SAL 4232.7

SAL 4232.8 argentino y la época de Pablo Podesta. Buenos Aires, 1929 Rela, Walter. El mito Santos Vega

la Plata. Montevideo, 1958. la Plata. 3a ed. Montevideo, 1966.

Castagnino, R.H. Contribución documental a la historia del teatro en Buenos Aires. Buenos Aires, 1944.

Beltrán, O.R. Las origenes del teatro argentino. Buenos

Aires, 1934.
Bianchi, A.A. Veintiuno años de teatro nacional. Buenos

Martinez, O. Historia del teatro en Bahia Blanca. Bahia

Blanca? |91?

American literature in Span of special forms - Drama - Special topics

Aires, 1960

GAL $4233.10 \quad$ Gallo Blas, Ra
Aires, 1959

SAL 4233.15 Capdevila, Art

Aires, 1951.

SAL 4234.1 - 99 Latin American literate

Argentina - History of special forms - Drama - Biographie

of actors, directos, etc. - Collected

SAL 4234.57 Muñoz, Andres. 30 vidas de artistas argentinos. Buenos Aires, 1940.

SAL 4235 Latin American literature in Spanish - Argentina - History

of special forms - Fiction - General works

SAL 4235.5 Garcia, Germán. La novela argentina; un itinerario. Buenos

Aires, 1954 . SAL 4235.12 Ghiano, J.C. Testimonio de la novela argentina. Buenos
SAL 4240.24

SAL 4240.26 ernández, Juan Romulo. Civilización argentina; la obra

imenez, Jorge C. Los delitos de imprenta. Buenos

SAL 4251 Latin American literature in Spanish - Argentina - General

anthologies, collections - General works - Other general

SAL 4251.1 Martinez, B.T. Antologia argentina, trozos historicos.

SAL 4251.2 Buenos Aires, 1890, 2v.

Gutierrez, J.M. Pensamientos, nt

SAL 4251.5.2 Benavento, G.O. Letras. 2a ed. Buenos Aires, 1930.

SAL 4251.10

SAL 4251.11 barguren, C. Le paysage et l'âme argentins. Buenos Aires, 1938 .

Cobello, José. Primera antologia lunfarda. Buenos Aires, 1961.

SAL 4251.30 Berdiales, G. Maestros del idioma. 9a ed. Buenos

Aires, 1941?

Bullrich Palenque, Sylvina. El compadrito, su destino. Buenos Aires, 1945

SAL 4251.35.2 Bullrich Palenque, Sylvina. El compadrito. 2a ed. Buenos

SAL 4251.40 Aires, 1968.

A El ombú la civilización. Santa Fe, 1955. Garganigo, John F. Antología de la literatura gauchesca y criollista. Montevideo, 1967

SAL 4251.44 Prieto, Adolfo. El periódico Màrtin Fierro. Buenos

SAL 4251.46

Aires, 1968. Ruffinelli, Jorge. La revista Caras y caretas. Buenos
Aires, 1968 .

SAL 4255 Latin American literature in Spanish - Argentina - General

anthologies, collections - Special periods
SAL 4255.10 Herriquez, U.P. Antologia clasica de la literatura argenting ?a ed Buenos Aires, 193a de la Presidencia. Mensajes a la 1. n.p., 1949. tias y poesia. Buenos Aires, 1961. Los conversadores. Buenos Aires, 1942

WIDENER LIBRARY SHELFLIST, 21

ardo. Los fundadores. Buenos

ardo. La literatura virreinal. Buenos

SAL 4258 Latin Ame..cian liter atus. ... spanısh - Argentina - General

thologies, collections - Local
SAL 4258.5 Celebración nacional...juegos florales. Tucuman, 1916.

SAL 4260 Latin American literature in Spanish - Argentina -

Anthologies of special forms - Poetry

SAL 4260.1 Poesias arjentinas. Buenos Aires, 1869. 3 pam.

SAL 4260.2 Poesias arjentinas. Buenos Aires, 1875. 4 pam.

SAL 4260.3 Poesias arjentinas. Buenos Aires, 1877. 4 pam.

Ascasubi, H. Aniceto el gallo...y otras poesías.

SAL 4260.5 Pamphlet vol. Poetry. Argentine Republic. 20 pam.

SAL 4260.5 
SAL 356.66 .100

SAL 4534.18

SAL 5269.1 .4
SAL 11567.54 .120

SAL 155.20 SAL 1460.12

SAL 388.41.100

SAL $1433.2 \mathrm{~F}$

SAL 1726.2 .3

SAL 5137.2 .2 .3 SAL. 250.17 .10

SAL 7164.1 .2

SAL 9196.77 .100

SAL 1609.1.10

SAL 60.25

SAL 375.83.100

SAL 1708.1.3

SAL 1729.41 .10

SAL 7119.41 .100

SAL 481.1 .8

SAL 5134.1.4

SAL 304.1 .6
Gimenez, J. Bibiana, ó los terremotos de Cuba. Gómez de 1852

Mez de Avellaneda, G. El héroe de Bailén; loa.

Gómez de Avellaneda, G. La hija de las flores, ó Todos estan locos. Madrid, 1852

Gez de Avellaneda, G. La verdad vence apariencias.

Heredia, José M. Poesias. La Habana, 1852.

Lorie, Antonio M. El viernes 20 de agosto en Cuba.

agariños Cervantes, A. Celiar, leyenda americana en

Zequeira y de metros. Madrid, 1852

Manuel. Poesias. Za ed. Habana, 1852

1853

Aguinaldo religio

Cuatro laudes por Ramon Zambrana. Habana, 1853.

Fernandez Lizardi, J.J. El periquillo sarniento, $5 \mathrm{a}$ ed. México, 1853. 4v.

Leon, J.S. de. Flores silvestres. Habana, 1853. 2 pam. Martinez Villergas, J. Sarmiento ó à mal Sarmiento. Paris, 1853.

Perso. Santiago de Chile, 1853. señora Condesa de Merlin. Memorias y recuerdos de Murmurios del canto. Cuba, 1853 .

Navarro, J.R. Guirnalda poetica. Mejico, 1853.

Ocio, José de Jesus de. IClavellinas L, poesias.

Matanzas, 185

Reglamento para los teatros de Mexico. Mexico, 1853

orres Caicedo, J.M. Colección de poesias orijinales.

Blest Gana, G.

Cardenas y Ch:

Corpancho, M

Gallego, Juan

Mármoi, José.

Mendive, R.M

Montaos y Ro

Matanzas, I

Pesado, J.J.

Ruiseco, Tomás. El genı español. Veracruz, 1854

Valdés Mendoza, M. Poesías. Habana, 1854

1855

Avila, Manuel. Revolución del Peru. Lima, 1855. Baudry, Libreria Europea. Obras de Vinageras. Juicio critico. Paris, 185

WIDENER LIBRARY SHELFLIST, 21

\section{CHRONOLOGICAL LISTING}

Bilbao, Francisco. Colección. n.p., 1855. 6 pam.

Fornaris, Jose. Poesias. Habana, i 855 .
SAL 8011.2 .5

SAL 9220.1 .37

SAL 361.5.31

SAL 363.3 .29

SAL. 372.50 .20

SAL 398.1.36 SAL 410.13 .100
SAL 5732.69 .12

SAL 5333.1 .6

SAL 5333.1 .7

SAL 475.1.1.5

SAL 475.1 .21

SAL 202.1.31

SAL 7908.1.5 SAL 5531.58.100

SAL 232.3 .32

SAL 237.1.2

SAL 5707.25 .115

SAL 420.3 .31

SAL 481.65 .100
Caracas, 1857.

D. L Leyendas, Caras, 1857 Antonio Cantos: colieç̧áo de poesias. 3a ed. Leipzig, 1857

Os Tymbicas; poema americano. Leipzig, 1857

Loma Ossorio, J.M. Flores sin fruto, o inspiracione poeticas. Rev. ed. Habana, 1857 .

Macedo, Joaquim M. de. A nebulosa; poema. Rio de Janeiro, 1857. Millan, José Agustin. Ohras dramáticas. V. 1-2. Habana, 1857 .

Otero, Rafael. Un coburgo. Matanzas, 1857.

Pichardo, E. Villaclara romántica. Villaclara, 1857.

Sanfuentes, S. Ricardo i Lucia. Santiago de Chile, 1857. 2v. Sanfuentes, S. Teudo. Santiago de Chile, 1857

Tolon, Miguel T. Flores i espinas. Matanzas, 1857. 3 pam. aldes, G. de la C. Poesias completas. Paris, 1857. Poesias de Placido. 3a ed.

$$
\text { N.Y., i857. 2v. }
$$

\section{8}

Acosta, Ignacio M. de. Romance historico y geográfico de la isla de Cuba. Matanzas, 1858

Alfonso, R.M. Las quejos de Venezuela. Caracas, 1858. Balmaseda, F.J. Fábulas morales. Hahana,

Bernal O., R. Viene por mi i carga con usted.

Bogota, 1858. 2 pam.

183. 2a

Blanchet, Emilio. Versos y prosa. Matanzas, 1858.

Corona fúnebre a la memoria de la virtuosa y bella senorita $s$ Fernandez de Castro y Trelles.

Los hijos naturales; drama en tres actas. do, J.H. Versos. Caracas, 1858 M. Alyra gemedora; poesias. Rio de Obra del primer hombre. n.p., 1858 as. $2 \mathrm{a}$ ed. Madrid, 1858. $2 \mathrm{v}$. ección de articulos y poesías. i8. cun, vomzan. Poesias. Matanzas, 858 . Bogotá, 1858.

Perez, Felipe. Jilma ó continuación de Los Pizarros. Bogotá, 858 .

Quintana, A.M. El retrato del diablo. Matanzas, 1858-59. (858-61, 2v.

Vinolas Pedro. El corazón de una actriz ó Sueño

realidad. Habana, 1858. 
as a whole, e.g., counts by class, by language, by place of publication, by date, as well as counts of serials, monographs, and volumes. Many of these statistics have already been obtained from the converted classes and used for management purposes.

The general research value of the bibliographical data contained in large research library catalogs has already been recognized and exploited to some extent by Dolby, Forsyth, and Resnikoff. ${ }^{9}$ They have used data from one of the published volumes of the Widener shelflist and are currently working with the computer tapes of other classes. ${ }^{10}$ Their views on the statistical uses of catalogs in machine readable form have been summarized as follows:

Library catalogs contain a wealth of information about the historic development of the many fields of human endeavor and the interrelations that bind these activities. Mechanization of the catalog permits exploitation of this information by workers in many fields of research. Analysis of the same information can greatly assist librarians in studying their own collections and in managing the acquisition of materials for the library. Many studies of this type can be conducted on random samples of the catalog, though more detailed work requires access to the entire collection in machine-readable form. ${ }^{11}$

\section{Conclusion}

In 1968 this author concluded a description of the shelflist conversion project with this statement:

As it now stands, the Widener shelflist program, like many other present library compuiter systems, is regarded as an interim system designed to extract the maximum return from a simple existing bibliographical record of the contents of the Library. It is expected that in time the system will become obsolete and the imperfect shelflist entries will be superseded by standard bibliographical records in the emerging $\mathrm{Li}$ brary of Congress MARC II format. . . . The expectation is that a central bibliographical agency will convert and distribute these entries. It seems reasonable to suppose, however, that this conversion effort is still some years in the future and that, in the meantime, Harvard will have realized a satisfactory return on its investment in converting an abbreviated bibliographical record. ${ }^{12}$

Developments during the two years that have passed since that statement was made only serve to confirm this brief assessment of the program.

\section{REFERENCES}

1. Richard De Gennaro, "A Computer Produced Shelflist," College \& $R e$ search Libraries 26, 4:311-315, 353 (July 1965).

2. - "Automation in the Harvard College Library," Harvard Library Bulletin 16:217-236 (July 1968).

3. Foster M. Palmer, "Conversion of Existing Records in Large Libraries, with Special Reference to the Widener Shelflist," in The Brasenose Conference on the Automation of Libraries, Proceed- ings of the Anglo-American Conference on the Mechanization of Libraries held at Oxford . . . 30 June-3 July 1966. (London and Chicago: Mansell, 1967), p.57-80.

4. Conversion of Retrospective Catalog Records to Machine Readable Form, A Study of a National Bibliographical Service; prepared by the RECON Working Task Force, Henriette D. Avram, Chairman. (Washington, D.C.: Library of Congress, 1969); see also, 
Richard De Gennaro, “A National Bibliographical Data Base in MachineReadable Form: Progress and Prospects," Library Trends vol. 18, no. 4: 537-50 (April 1970).

5. James L. Dolby, V. J. Forsyth, and H. L. Resnikoff, Computerized Library Catalogs: Their Growth, Cost and Utility (Cambridge, Mass.: M.I.T. Press, 1969), p.25.

6. Don M. Avedon, Computer Output Microfilm (NMA Monograph No. 4). (Annapolis, Md.: National Microfilm Association, 1969).

7. The Institute of Library Research at the University of California, Berkeley, is operating such a system in a research environment, as are several other groups.

8. Foster M. Palmer, Widener Library Circulation Statistics 1965-1969: Book Use and Stack Space (Unpublished working paper. March 1970). 18p.

9. Dolby, Computerized Library Catalogs (Chapter 6: "On Economic Growth of Nations and Archival Collections"). p.115-33.

10. Ibid., (Chapter 1), p.1-19.

11. Ibid., p.17.

12. De Gennaro, "Automation in the Harvard College Library,” p.229. 